\title{
Collocation Errors by Indonesian EFL Learners: Types of Errors, Translation Techniques, and Causes of Errors
}

\author{
Ni Luh Putu Setiarini \\ English Department \\ Universitas Gunadarma \\ Depok, Indonesia \\ nlpsetiarini@gmail.com
}

\begin{abstract}
The limited exposure of English causes the production of collocation errors by learners of English as a foreign language (EFL). In addition, the arbitrary characteristics of collocation and learners' lower linguistic level result the errors. This study aims to investigate the types of collocation errors mostly found in translating Indonesian collocations into English by the EFL learners, to identify the translation techniques used by them and to find out the cause of the collocation errors. The EFL learners are the students of Faculty of Language and Literature, English Department, academic year 2017/2018, Universitas Gunadarma. The study uses two Indonesian folk stories entitled Lang Kunduk and Lebang Sialang and the translation of the two stories in English by the EFL learners. The method used in this study is descriptive analytical approach. A total of 98 collocations were identified in the two stories. The results show that the most frequent collocation translation errors made by the EFL leaners are lexical errors; meanwhile, the second most frequent collocation translation errors are grammatical errors. With regard to translation techniques, the six most frequently used translation techniques found are discursive creation, generalization, linguistic compression, reduction, modulation and literal translation. Those collocation errors are caused by interlingual transfer or native interference errors, i.e. the errors caused by the influence of the native language. Meanwhile, some errors are caused by intralingual errors, i.e. the errors caused by the influence of the second or foreign language.
\end{abstract}

Keywords-collocation errors; interlingual transfer; intralingual errors; translation techniques

\section{INTRODUCTION}

Errors in acquiring a foreign or second language cannot be avoided by learners. They pervasively occur. Richards (1974) defines errors as the differences between the ways people speak and the way native speakers use their language. Errors also occur when students inappropriately pair or arrange lexical items in a text, in other words, they unnaturally put words side by side (Shitu, 2015). The successful achievement of leaners in learning a foreign language is indicated by their abilities in producing words as the way native speakers do or sequencing words side by side correctly. Firth (as cited in Seretan, 2011) calls this sequence of words collocation. He defines collocation as the company that words keep. Nation (2001) refers collocation as a group of words that come together. Benson, Benson, and Ilson (2010) classify collocation into two main categories. They are lexical collocation and grammatical collocation. Lexical collocations are made up of content words. In other words, they are comprised of noun, verb, adjective, and adverb. With regard to grammatical collocation, they are composed of content words and prepositions. The basic difference between lexical collocations and grammatical collocations is that the former do not contain prepositions, infinitives or clauses; they only contain content words. Meanwhile, the latter contain content words together with preposition, infinitives and clauses.

Collocation has become problems for learners due to different ways in juxtaposing words between one language and the other. The differences lead learners in committing errors. The errors occur in the outputs of learning: speaking and writing. It is worth nothing that errors also occur in translation. In translation, the errors have widely occurred if the collocation of source language text (SLT) cannot be translated literally into target language text (TLT). Moreover, problems arise when the collocations are categorised as broader collocation range, in which various words can be put side by side after or before the node of the collocation (Baker, 2011, p. 54). These sequences result in various meanings and vast collocations. Let's take the example of the Indonesian collocation mengikuti ujian (take an exam). Leaners will fail to translate this collocation correctly when they translate mengikuti into follow. In English, follow does not collocate with exam. Mengikuti should be equalised with take, thus mengikuti ujian should be transferred in English into take an exam. Another example is the collocation mencuci piring (do the dishes). Mencuci (wash) in mencuci pring (do the dishes) cannot be translated literally into *wash the plates in English. The occurrence of wash after plates does not produce natural occurrence or acceptable collocation. Mencuci piring is to be equalized as do the dishes in English. Indonesian collocation lalu lintas padat (traffic jam) cannot be translated literally into English. Translating this collocation literally into English (*solid traffic) produces unacceptable collocation. 
The equivalence of lalu lintas padat in English is heavy traffic.

Several studies on errors in translating collocation have already been conducted by some scholars. Moekardi (2002) conducted a research on grammatical and lexical problems by EFL learners. She found out three main problems faced by the Indonesian EFL learners. They have problems in translating noun-verb collocation, adjective-noun collocation, and the third problem they face is the using of the word very repeatedly in all sequence of area. Another scholar who conducts a study on the collocation errors is Mahmoud. Mahmoud (2005) investigates errors made by the students of Arab in translating Arab collocations into English. He found more errors on lexical collocation rather than grammatical collocation errors. Gitsaki (1997) also conducts a study on the errors in translating collocation. She revealed that EFL learners had deficiency in producing acceptable collocations. The other reasons in producing errors in collocation is lack of collocation knowledge. Besides, the errors are also influenced by their native language. A study on errors in translating collocation is also conducted by Koya (2005). She studied on the factors influencing the difficulty in collocation. The factors are the differences between the characteristics and the patterns of collocation in students' mother tongue and the collocation in the second or foreign language. The others are the arbitrariness, maturation, complexity, language proficiency, teaching, and saliency. She also concluded that the most difficult collocation is adjective-noun collocation. Moreover, Alsulayyi (2015) investigated the production of English grammatical collocations amongst Saudi students majoring in English in the USA and those in the UK. The findings revealed that the highest number of errors in both groups was recorded on the grammatical collocations patterns, noun-preposition and adjective-preposition. She added that their mother tongue interference plays a crucial role in students' erroneous responses, especially those which contain a preposition.

Many studies on collocation errors made by EFL learners are focused on the categories of errors and causes of errors. However, a few studies analyse the translation techniques applied by the learners in translating collocation from their first language (L1) into the second/foreign language (L2). The present study addresses the following questions: 1) What types of collocation errors were made by the Indonesian EFL learners in translating Indonesian collocation into English? 2) What translation techniques were applied by the Indonesian EFL learners in translating Indonesian collocation into English? 3) What are the causes of the errors?

\section{METHOD}

A total of 52 Indonesian EFL learners were asked to translate the Indonesian folk stories into English. The EFL learners are the students of English Department, Universitas Gunadarma, academic year 2017/2018. The materials of the study were two Indonesian folk stories entitled Lebang Sialang and Lang Kunduk and the students' translation. These two folk stories are told from generation to generation by the speakers of Jambi (Yanti, Tadamor, Cole, \& Hermon, 2015). Methods used in this study were quantitative and qualitative. The occurrence of the errors in translating Indonesian collocation are quantitatively counted. The method used in this study is descriptive analytical approach. The data are described and analysed quantitatively and qualitatively. The total usage of the translation techniques are analysed quantitatively, meanwhile the causes of the collocation errors are analysed qualitatively. While translating the texts, they were not allowed to open any kinds of dictionaries. The reason of prohibiting them using the dictionaries is to find out their L2's collocation competence. The translation projects took two days. On the first day, they translated Lebang Sialang and on the following week they translated Lang Kunduk. A total of 98 Indonesian collocations were identified. The data of collocation errors were divided into two main categories: grammatical errors and lexical errors. Next, the writer identified the translation techniques used by the EFL learners. The writer compared the learners' translation and the SLT. Then, the data were categorised into causes of errors: interlingual transfer and intralingual errors.

\section{RESULT AND DISCUSSION}

The findings of the study show that learners do two kinds of errors in translating L1's collocation into L2's collocation. The errors are categorised into lexical errors and grammatical errors. Out of 98 collocations, 80 collocations are classified as lexical collocations and 18 are syntactic collocations. Sixty lexical collocations are found in Lang Kunduk folk story and 20 lexical collocations are found in Lebang Sialang folk story. Meanwhile, 11 collocations in Lang Kunduk belong to grammatical collocations and 7 collocations in Lebang Sialang belong to grammatical collocations.

The distribution of grammatical collocation errors and lexical collocation errors found in the learners' translation can be shown in Figure 1. Based on Figure 1, a total of 121 lexical collocation errors is found in Lang Kunduk and a total of 68 lexical errors is found in Lebang Sialang. Meanwhile, the grammatical collocation errors in Lang Kunduk are 108 data and the grammatical collocation errors in Lebang Sialang are 51 data. Consequently, the errors in lexical collocations are higher than those in grammatical collocations.

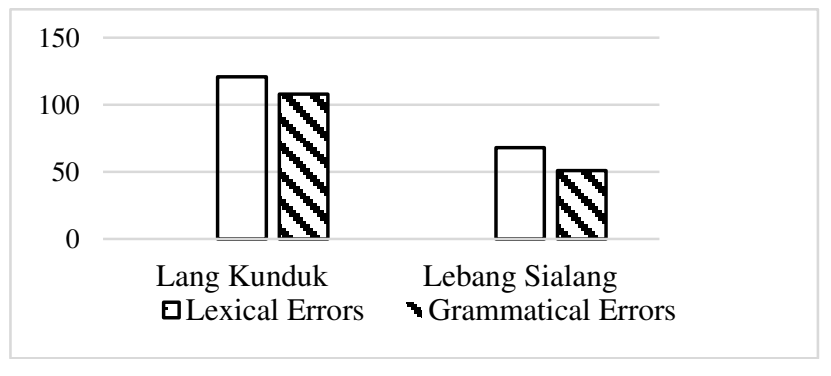

Figure 1: Lexical errors and syntactic errors 
The collocation errors made by the learners are influenced by the application of translation techniques. Besides, those errors are also caused by two causes of errors; which are interlingual transfer and intralingual errors. The identification of the translation techniques used and the causes of lexical collocation errors is presented in Table 1. As shown in Table 1, lexical collocation errors are caused by interlingual transfers and intralingual errors.

TABLE I. THE TRANSLATION TECHNIQUES AND CAUSES OF ERRORS RESULTED IN LEXICAL COLLOCATION ERRORS

\begin{tabular}{|c|c|c|c|c|}
\hline \multirow{3}{*}{\multicolumn{2}{|c|}{ Causes of Error }} & \multicolumn{3}{|c|}{$\begin{array}{c}\text { Translation Techniques Used in Two } \\
\text { Folk Stories }\end{array}$} \\
\hline & & \multirow{2}{*}{$\begin{array}{c}\text { Kinds of } \\
\text { Translation } \\
\text { Techniques }\end{array}$} & \multicolumn{2}{|c|}{$\begin{array}{c}\text { Frequency of Lexical } \\
\text { Collocation Errors }\end{array}$} \\
\hline & & & $\begin{array}{c}\text { Lang } \\
\text { Kunduk }\end{array}$ & $\begin{array}{l}\text { Lebang } \\
\text { Sialang }\end{array}$ \\
\hline \multirow[t]{7}{*}{$\begin{array}{l}\text { Interlingual } \\
\text { transfers }\end{array}$} & \multirow{4}{*}{$\begin{array}{l}\text { The wrong } \\
\text { selection of } \\
\text { word }\end{array}$} & $\begin{array}{l}\text { Discursive } \\
\text { creation }\end{array}$ & 29 & 11 \\
\hline & & Modulation & 9 & 6 \\
\hline & & Generalization & 7 & 5 \\
\hline & & $\begin{array}{l}\text { Literal } \\
\text { translation }\end{array}$ & 20 & 12 \\
\hline & $\begin{array}{l}\text { The wrong } \\
\text { selection of parts } \\
\text { of speech }\end{array}$ & $\begin{array}{l}\text { Literal } \\
\text { translation }\end{array}$ & 19 & 9 \\
\hline & $\begin{array}{l}\text { Literal } \\
\text { translation }\end{array}$ & $\begin{array}{l}\text { Literal } \\
\text { translation }\end{array}$ & 20 & 11 \\
\hline & Not translated & Reduction & 8 & 6 \\
\hline $\begin{array}{l}\text { Intralingual } \\
\text { errors }\end{array}$ & $\begin{array}{l}\text { The wrong } \\
\text { selection of } \\
\text { pronoun }\end{array}$ & Generalization & 9 & 8 \\
\hline
\end{tabular}

Out of 121 lexical collocation errors found in Lang Kunduk, most of them are caused by interlingual transfer. The interlingual transfers are classified as the wrong selection of word, the wrong selection of parts of speech, literal translation and collocations not translated into TLT. Similarly, from 68 lexical collocation errors found in Lebang Sialang, most of them are caused by interlingual transfer. By contrast, both in Lang Kunduk and Lebang Sialang, few errors are caused by intralingual errors. This error is referred as the wrong selection of pronoun. With regard to translation techniques, as presented in Table 1, the learners use discursive creation, literal translation, modulation, generalization and reduction.

TABLE II. THE TRANSLATION TECHNIQUES AND CAUSES OF ERRORS RESULTED IN GRAMMATICAL COLLOCATION ERRORS

\begin{tabular}{|c|c|c|c|c|}
\hline \multirow{3}{*}{\multicolumn{2}{|c|}{ Causes of Error }} & \multicolumn{3}{|c|}{$\begin{array}{c}\text { Translation Techniques Used in } \\
\text { Two Folk Stories }\end{array}$} \\
\hline & & \multirow[t]{2}{*}{$\begin{array}{c}\text { Kinds of } \\
\text { Translation } \\
\text { Techniques }\end{array}$} & \multicolumn{2}{|c|}{$\begin{array}{c}\text { Frequency of } \\
\text { Grammatical } \\
\text { Collocation Errors }\end{array}$} \\
\hline & & & $\begin{array}{c}\text { Lang } \\
\text { Kunduk }\end{array}$ & $\begin{array}{l}\text { Lebang } \\
\text { Sialang } \\
\end{array}$ \\
\hline \multirow[t]{2}{*}{$\begin{array}{l}\text { Interlingual } \\
\text { transfer }\end{array}$} & \multirow[t]{2}{*}{$\begin{array}{l}\text { The use of L1 } \\
\text { structure }\end{array}$} & $\begin{array}{l}\text { Linguistic } \\
\text { compression }\end{array}$ & 21 & 7 \\
\hline & & Reduction & 10 & 6 \\
\hline \multirow[t]{2}{*}{$\begin{array}{l}\text { Intralingual } \\
\text { errors }\end{array}$} & $\begin{array}{l}\text { The wrong } \\
\text { selection of } \\
\text { preposition }\end{array}$ & $\begin{array}{l}\text { Literal } \\
\text { translation }\end{array}$ & 18 & 8 \\
\hline & The wrong & Discursive & 42 & 20 \\
\hline
\end{tabular}

\begin{tabular}{|l|l|l|l|l|}
\hline & $\begin{array}{l}\text { selection of } \\
\text { tense }\end{array}$ & creation & & \\
\cline { 2 - 5 } & $\begin{array}{l}\text { The wrong } \\
\text { selection of } \\
\text { kinds of verb }\end{array}$ & $\begin{array}{l}\text { Discursive } \\
\text { creation }\end{array}$ & 17 & 10 \\
\hline
\end{tabular}

Based on Table 2, in contrast to lexical collocation errors, the errors on grammatical collocations are mostly caused by intralingual errors rather than by interlingual transfers. They are found both in the translation of Lang Kunduk and in the translation of Lebang Sialang. One kind of interlingual transfer, i.e. the use of L1's structure is found in the data. This error is also influenced by the translation techniques; which are linguistic compression and reduction. The causes of errors classified as intralingual errors are the wrong selection of preposition, the wrong selection of tense and the wrong selection of kinds of verbs. These errors are due to the usage of translation techniques: literal translation and discursive creation.

Example 1 represents error in translating collocation hidup susah (a hard life) into English.

\section{Example 1:}

SLT: Ibunya hidup susah.

Learners' translation: His mother lived hard.

Suggested translation: His mother had a hard life.

The learners' translation in example 1 represents lexical collocation error. The lexical error occurs when a translator assumes that the SLT collocation can be translated literally. The lexical error is reflected in the translation of hidup susah into *live hard. The learners literally translated hidup into lived and susah into hard. It is not natural in English to convey the message of having a hard life into *somebody lived hard. The result of the translation is influenced by the application of literal translation. To sound naturally, Ibunya hidup susah should be transferred into His mother had a hard life. The cause of the error is influenced by the learners' mother tongue. They assume that the collocation in Indonesian can be translated literally into English. The error caused by leaners' mother tongue is categorised into interlingual error.

\section{Example 2:}

SLT: Setiap hari ibunya mengambil kayu api di hutan.

Learners' translation: Everyday his mother took firewood in the forest.

Suggested translation: Everyday his mother would go to the forest to collect firewood.

Based on the criteria of accuracy and acceptability, the translation of Example 2 into Indonesian is correct and acceptable. However, in order to convey the meaning of habitual activity in the past, English has a specific pattern, i.e. would followed by infinitive. Naturally, the message of Setiap hari ibunya mengambil kayu api di hutan can be transferred in English into Everyday his mother would go to the forest to collect firewood. The grammatical pattern of would go to the forest to collect firewood is equivalent to setiap hari mengambil kayu api. The translation technique applied by the leaners is discursive creation. Leaners' errors in translating collocation from L1 into L2 are not only influenced by L1 rules. Errors occur when the leaners are 
influenced by the L2. Leaners' translation shown in Example 2 occurs due to the influence of English. Learners overgeneralized that the activity in the past is only realized in the simple past verb.

Example 3:

SLT: Ibunya dicaci-maki.

Learners' translation: His mother was vituperation.

Suggested translation: He would scold his mother.

The error in Example 3 is categorised into both grammatical and lexical error. The lexical error is reflected in the usage of vituperation which comes after his mother. The surface structure of His mother was vituperation indicates that his mother is a kind of vituperation. This clause is grammatically incorrect. Moreover, this translation results in the error of meaning as vituperation is not identical with somebody. This kind of error is influenced by lack of collocation competence and also by the use of translation technique applied by the learners. The use of discursive creation results in grammatical error and lexical error. The suggested translation of Ibunya dicaci-maki is He would scold his mother. The use of modulation in the suggested translation gives positive impact on the accuracy, acceptability and readability of the translation of this clause. This kind of error is caused by the intralingual error, specifically ignorance of rule restriction. James (1998) stated that ignorance of rule restriction is referred as the learners of the second language do not obey the structure of the target language.

\section{Example 3:}

SLT: Ibunya sedang kurang enak badan.

Learners' translation: His mother feels tired.

Suggested translation: His mother did not feel very well.

Grammatically, the learners' translation in Example 4 is correct. However, the message is not equivalent to the message of SLT. The expression of kurang enak badan is not equivalent to feeling tired. Kurang enak badan could be transferred into did not feel very well. The change of point of view made by the learners does not bring about good impact on the equality of the translation. This inequivalent correspondence results in lexical collocation error. The error is caused by intralingual transfer. This error is categorised into false concept hypothesis. James (1998) argues that false concept hypothesized is meant by the learners' faulty understanding of distinctions of target language items. This leads to false conceptualization.

\section{CONCLUSION}

This study has discussed the types of errors, translation techniques and the causes of errors in the translation of Indonesian collocation into English by Indonesian EFL learners. With regard to the types of collocation errors, the findings show that there are two kinds of collocation errors; which are lexical collocation errors and grammatical collocations errors. The lexical collocation errors occurred higher than the grammatical collocation errors. The translation techniques resulting in the two kinds of errors are discursive creation, generalization, linguistic compression, reduction, modulation and literal translation. Meanwhile, the causes of errors in lexical collocation errors are mostly identified as interlingual transfers than intralingual errors. In contrast, the errors in grammatical collocation are mostly caused by intralingual errors than interlingual transfers.

\section{References}

Alsulayyi, M. N. (2015). The use of grammatical collocations by advanced Saudi EFL learners in the UK and USA. International Journal English Linguistics, $5(1)$.

Baker, M. (2011). In other words: a course book on translation. $\left(2^{\text {nd }}\right.$. ed.). London: Routledge.

Benson, M., Benson, E., \& Ilson, R. (2010). The BBI combinatory dictionary of english: your guide to collocation and grammar. Amsterdam: John Benjamin Publishing Company.

Gitsaki, C. (1996). The development of esl collocation knowledge. (Unpublished doctoral thesis). The University of Queensland. Queensland.

James, C. (1998). Errors in language learning and use: exploring error analysis. New York: Longman.

Koya, T. (2005). The acquisition of basic collocations by Japanese learners of English (unpublished doctoral thesis), Waseda University, Tokyo.

Mahmood, A. (2005). Collocation errors made by Arab learners of English. Asian EFL Journal: English Language Teaching and Research, Article 2, 1-9.

Moekardi, R. R. D. (2000). Grammatical and lexical english collocation: some possible problems indonesian students of english. Humaniora, 14, 53-62.

Nation, I. P. (2001). Learning vocabulary in another language. Cambridge: Cambridge University Press.

Richards, J. C. (Ed.). (1974). Error analysis: perspectives on second language acquisition. London: Longman.

Seretan, V. (2011). Syntax - based collocation extraction: text speech and language. Springer Science Business Media B. V.

Shitu, F. M. (2015). Collocation errors in english as second language (esl) essay writing. Journal of Cognitive and Language Science, 9(9).

Yanti, Tadamor, U., Cole, P., Hermon, G. (Eds). (2015) Crito kito: a collection of jambi stories in the seberang dialect. Masyarakat Linguistik Indonesia: Jakarta. 